\title{
NOTE ON THE CIPPUS ABELLANUS
}

In Professor Buck's Grammar of Oscan and Umbrian, p. 226, the inscription on the Cippus Abellanus 1. $15 \mathrm{f}$., "paí teremenniú múnníkad tanginúd prúftúset ríhtúd amnúd," is translated "quae termina communi sententia posita sunt recto circuitu." On p. 202, section 291, as an illustration of the ablative of the route, "ríhtúd amnúd" is rendered "right around in a circle," and is compared with "L. sursum (deorsum) rivo recto (iugo recto)," "right up (down) the stream (ridge)" (C.I.L., I, 199). I should like to suggest "directo ambitu" as a translation for "ríhtúd amnúd." The reference would then be to an inclosure bounded by straight lines, a temple yard, square or oblong, it might be. These words are used in Vegetius' Epitoma rei militaris, referring to a city wall composed of straight lines in distinction from one where the lines are curved or broken:

4. 2. Ambitum muri directum veteres ducere noluerunt, ne ad ictus arietum esset expositus, sed sinuosis anfractibus, iactis fundamentis, clausere urbes, crebrioresque turres in ipsis angulis reddiderunt propterea, quia, si quis ad murum tali ordinatione constructum vel scalas vel machinas voluerit admovere, non solum a fronte sed etiam a lateribus et prose a tergo velut in sinu circumclusus obprimitur.

Washburn College

IRENE NYE

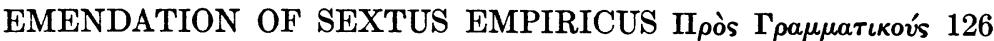

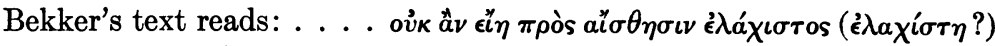

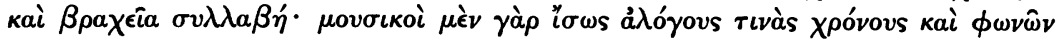

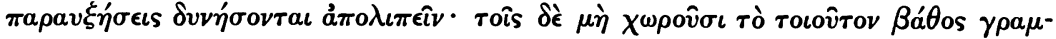

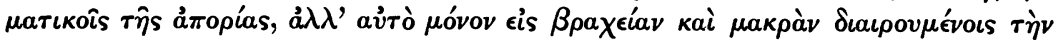

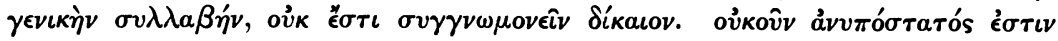
¡ं $\beta \rho a \chi \epsilon \hat{\imath} a$ $\sigma v \lambda \lambda a \beta \eta^{\prime}$.

Sextus is picking holes in the elementary theory of the grammarians; they divide all syllables into "short" and "long," and thereby are committed, he has argued, to the assumption that the short syllable is the shortest time, if not $\pi \rho \grave{s} \phi \dot{v} \sigma \iota v$, at least $\pi \rho o{ }^{2}$ al $\sigma \theta \eta \sigma \iota v$. But in the "short" syllable $\epsilon \rho$, for example, he objects that we are distinctly conscious of the separate times of $\epsilon$ and $\rho$. The "short" syllable, then, is not the shortest time, even

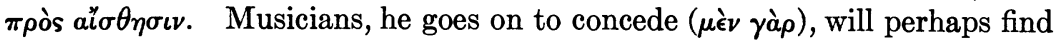
an evasion of this difficulty in their doctrine of irrational times, protractions, etc. But we can allow no escape from the ämopía for rigid grammarians who admit no such rhythmical modification of syllables, but hold to the absolute classification, "short" or "long." Such is the purport of the argument. But it is impossible to get this meaning out of the words as they stand, or indeed I think to put any rational construction upon them. We probably have before us one of the not infrequent passages in later and little-edited authors 